\title{
CHEMOSPHERE
}

\section{Methane and carbon dioxide emissions from Shan-Chu-Ku landfill site in northern Taiwan}

\author{
Ullas Hegde ${ }^{1}$, Tsan-Chang Chang, Shang-Shyng Yang * \\ Department of Biochemical Science and Technology, National Taiwan University, Taipei 10617, Taiwan, ROC
}

Received 19 February 2003; received in revised form 10 March 2003; accepted 13 March 2003

\begin{abstract}
To investigate the methane and carbon dioxide emissions from landfill, samples were taken of material up to 5 years old from Shan-Chu-Ku landfill located in the northern part of Taiwan. Atmospheric concentrations of carbon dioxide, methane and nitrous oxide ranged from 310 to $530,2.64$ to 20.16 and 0.358 to 1.516 ppmv with the measurement of gastype open-path Fourier transform infra-red (FTIR) spectroscopy during February 1998 to March 2000, respectively. Average methane emission rate was $13.17,65.27$ and $0.99 \mathrm{mg} \mathrm{m}^{-2} \mathrm{~h}^{-1}$ measured by the gas chromatography chamber method in 1-2, 2-3 and 5 year-old landfill, respectively. Similarly, average carbon dioxide emission rate was 93.70 , 314.60 and $48.46 \mathrm{mg} \mathrm{m}^{-2} \mathrm{~h}^{-1}$, respectively. About 2-3 year-old landfill had the highest methane and carbon dioxide emission rates among the tested areas, while 5 year-old landfill was the least. Methane emission rate at night in most tested locations was higher than that in the daytime. Total amount of methane and carbon dioxide emission from this landfill was around 171 and 828 ton in 1999, respectively.
\end{abstract}

(c) 2003 Elsevier Ltd. All rights reserved.

Keywords: Fourier transform infra-red spectroscopy; Greenhouse gas; Landfill; Methane and carbon dioxide emission rate

\section{Introduction}

Anaerobic decomposition of landfilled solid waste generates significant amounts of greenhouse gas comprising $60 \%$ methane and $40 \%$ carbon dioxide $(\mathrm{v} / \mathrm{v})$, together with numerous trace gases. Landfills have been implicated as the largest anthropogenic source of atmospheric methane in the world (Bogner et al., 1997) and as a significant contributor to global warming in greenhouse gas scenarios. On a global scale, approximately $653 \mathrm{Tg} \mathrm{yr}^{-1}$ of waste is landfilled and annual

\footnotetext{
${ }^{*}$ Corresponding author. Tel.: +886-2-2362-1519; fax: +8862-2367-9827.

E-mail address: ssyang@ccms.ntu.edu.tw (S.-S. Yang).

${ }^{1}$ Permanent address: Post Graduate School for Biological Studies, Ahmednagar College, Ahmednagar 414 001, Maharastra State, India.
}

global methane emission from landfills ranged from 9 to $70 \mathrm{Tg}$ (Kreileman and Bouwman, 1994).

Compared to wetlands and paddy fields, landfills function as a closed system because of controlled burial of biodegradable organic materials. The management, composition, moisture content and $\mathrm{pH}$ of the refuse influence methane and carbon dioxide production in landfills. Methanogenesis occurs when the organic waste $\mathrm{pH}$ is between 6.8 and 7.4 and is stimulated with increasing moisture content (Gurijala and Sulflita, 1993; Jang and Yang, 2001). On-field measurements of greenhouse gas concentrations and emissions from landfill are surprisingly few, despite the fundamental physical differences between aquatic and terrestrial ecosystems. The Shan-Chu-Ku landfill is the main landfill in northern Taiwan. The methane and carbon dioxide emission pattern of the Shan-Chu-Ku landfill is different from other landfills because of differences in refuse composition, landfill management, environmental conditions and methane oxidation activity by microorganisms 
present in the soils covering the landfill (Liao et al., 1998; Kuo et al., 2000). In this study, we have measured the methane and carbon dioxide emissions from municipal solid waste (MSW) material of various ages, 1-2, 2-3 and 5 year-old, of the Shan-Chu-Ku landfill and the seasonal variation of greenhouse gas concentration in the 2-3 year-old material has also been studied during February 1998-March 2000.

\section{Materials and methods}

\subsection{Site description}

The Shan-Chu-Ku landfill $\left(25^{\circ} 02^{\prime} \mathrm{N}, 120^{\circ} 32^{\prime} \mathrm{E}\right)$ is situated near Taipei City in northern Taiwan. It covers 65 ha of area, out of which 30 ha are currently in use for landfilling of MSW. It was started in June 1994 and is predicted to be in use for at least 10 years. At present it receives daily approximately 1400 ton of MSW (it received 1100 ton of MSW at the initial period). The compositions of MSW are listed in Table 1. Sampling locations of material deposited 1-2, 2-3 and 5 years ago were chosen in this study. The properties of cover soils at different burial periods are also shown in Table 2. The campus of National Taiwan University (NTU) $\left(25^{\circ} 01^{\prime} \mathrm{N}, 120^{\circ} 31^{\prime} \mathrm{E}\right)$ is also located in Taipei City. The grass area in the open field near the library is used for comparison of the gas chromatography (GC) and
Fourier transform infra-red (FTIR) spectroscopy as methods of measuring atmospheric methane and carbon dioxide concentrations.

\subsection{Gas-type open-path FTIR spectroscopy measurement}

FTIR spectroscopy method was used to investigate the concentrations of atmospheric greenhouse gas as follows: with a height $197 \mathrm{~cm}$ above ground and a scan number 100 in $7 \mathrm{~min}$, absorbance at wave numbers between 2239 and $2393 \mathrm{~cm}^{-1}$ for carbon dioxide, 2999 $\mathrm{cm}^{-1}$ for methane, and between 2214 and $2236 \mathrm{~cm}^{-1}$ for nitrous oxide measurement. The distance between the light source and the reflecting mirror was $25 \mathrm{~m}$. The details of the experimental set-up adopted for FTIR spectroscopy method was described in our previous paper (Chang et al., 2000). As the interferometer characteristics dominated by a high spectral resolution up to $0.06 \mathrm{~cm}^{-1}$ and a configuration suitable for field measurements, the MB-104 (BOMEM, Hartmann \& Braun, Canada) is used for radiation emission as well as absorption measurement. Observing the spectrum on a PC screen and adjusting the mirror achieve signal optimization. The atmospheric concentrations of greenhouse gas from long-path measurement are determined by the differential absorption, a least square fit of measurement, and simulated by modeling the air transmittances for various absorbed concentrations.

Table 1

Properties of MSW produced in Taiwan

\begin{tabular}{lrrrrr}
\hline & Year & & & \\
\cline { 2 - 5 } & 1992 & 1995 & 1997 & 1999 & $1999^{\mathrm{a}}$ \\
\hline Food waste (\%) & 25.73 & 17.94 & 24.90 & 21.83 & $40.29 \pm 6.36$ \\
Paper (\%) & 24.86 & 32.17 & 29.13 & 35.83 & $33.11 \pm 4.33$ \\
Plastic (\%) & 19.14 & 18.27 & 19.57 & 19.85 & $15.10 \pm 2.22$ \\
Wood (\%) & 5.06 & 5.82 & 4.86 & 5.89 & $3.47 \pm 2.24$ \\
Textile \& litter (\%) & 3.97 & 6.21 & 5.80 & 0.60 & $0.95 \pm 0.43$ \\
Leather (\%) & 1.73 & 0.88 & 1.13 & 4.99 & $2.89 \pm 2.11$ \\
Glass (\%) & 7.69 & 5.59 & 4.95 & 3.80 & $2.88 \pm 3.27$ \\
Metal (\%) & 7.07 & 6.05 & 5.33 & 0.51 & $0.06 \pm 0.06$ \\
Porcelain (\%) & 0.83 & 1.64 & 1.26 & 2.50 & $0.02 \pm 0.01$ \\
Others (\%) & 3.93 & 5.45 & 3.07 & & \\
\hline
\end{tabular}

${ }^{\mathrm{a}} \mathrm{MSW}$ produced in Taipei City, means \pm S.D. $(n=3)$.

Table 2

Properties of cover soils in the Shan-Chu-Ku landfill

\begin{tabular}{|c|c|c|c|c|c|c|c|}
\hline $\begin{array}{l}\text { Disposal } \\
\text { period (year) }\end{array}$ & Texture & $\begin{array}{l}\text { Soil depth } \\
(\mathrm{cm})\end{array}$ & $\begin{array}{l}\text { Moisture } \\
\text { content }(\%)\end{array}$ & $\begin{array}{l}\text { Soil } \\
\text { temperature }\left({ }^{\circ} \mathrm{C}\right)\end{array}$ & $\begin{array}{l}\text { Organic } \\
\text { carbon }(\%)\end{array}$ & $\begin{array}{l}\text { Total } \\
\text { nitrogen }(\%)\end{array}$ & Vegetation \\
\hline $1-2$ & Loam, sandy loam & 130 & $23.09 \pm 4.02$ & $21.5 \pm 3.2$ & $6.73 \pm 0.76$ & $0.29 \pm 0.05$ & Grass, fern \\
\hline $2-3$ & Loam, clay loam & 140 & $22.72 \pm 3.98$ & $22.4 \pm 4.1$ & $8.40 \pm 0.62$ & $0.31 \pm 0.07$ & Grass, fern \\
\hline 5 & Loam & 180 & $22.16 \pm 2.25$ & $21.0 \pm 2.8$ & $6.30 \pm 0.46$ & $0.26 \pm 0.05$ & $\begin{array}{l}\text { Grass, fern, } \\
\text { small shrubs }\end{array}$ \\
\hline
\end{tabular}

Means \pm S.D. $(n=15)$. 


\subsection{Carbon dioxide and methane emission rate}

Gas samples were collected using a homemade closed acrylic chamber (length $40 \mathrm{~cm}$, width $40 \mathrm{~cm}$ and height $65 \mathrm{~cm}$, about 96 1) that was equipped with an electronic fan, a thermometer and a sampling hole. For measuring carbon dioxide and methane emission rates, four acrylic chambers were installed on the surface of landfill soils in each measurement. Grass and small plants are cut from the cover soil to avoid plant respiration and photosynthesis. The chambers were placed on the soil surface with $5 \mathrm{~cm}$ inserted into the soil $10 \mathrm{~min}$ prior to each sampling for equilibration to reduce the disturbance to the sampling site. $35 \mathrm{ml}$ gas samples were collected from the headspace of the chamber and transferred to a 12.6 $\mathrm{ml}$ serum bottle that had been sealed by a butyl rubber stopper and flushed with oxygen-free nitrogen gas (Chang and Yang, 1997). Gas samples were collected from the chamber at 30-min intervals for $1 \mathrm{~h}$, and sampled again $3 \mathrm{~h}$ later for comparison. The methane and carbon dioxide concentration and the accumulated time from 0 to $2 \mathrm{~h}$ in four chambers had linear relationship and correlation coefficient $r^{2}=0.99$ and 0.98 , respectively. The rates of carbon dioxide and methane emissions were calculated by fitting linear regression to the difference in the carbon dioxide and methane concentrations and adjusting for the chamber volume and area covered following the equation (Rolston, 1986):

$f=(V / A)(\Delta C / \Delta t)$

where $f$ is the carbon dioxide or methane emission rate $\left(\mathrm{mg} \mathrm{m}^{-2} \mathrm{~h}^{-1}\right) ; V$, the volume of chamber above soil $\left(\mathrm{m}^{3}\right)$; $A$, the cross-section of chamber $\left(\mathrm{m}^{2}\right) ; \Delta C$, the concentration difference between time zero and time $t\left(\mathrm{mg} \mathrm{m}^{-3}\right)$ and $\Delta t$, the time duration between two sampling periods (h). The total carbon dioxide or methane emission from landfills was the summation of carbon dioxide and methane emissions in all year (Yang and Chang, 1998).

Atmospheric carbon dioxide and methane were also analyzed by GC method. Gas sample was collected in the center of line determination by FTIR spectroscopy method at $197 \mathrm{~cm}$ height as the instrument measurement.

Methane concentration was analyzed by a Shimadzu 14A gas chromatograph (Shimadzu Co., Japan) with a glass column $(0.26 \mathrm{~mm} \times 2.0 \mathrm{~m})$ and a flame ionization detector, which was packed with Porapak Q (80/100 mesh). The column temperature was set at $100{ }^{\circ} \mathrm{C}$, the injection and the detector temperatures were set at 130 ${ }^{\circ} \mathrm{C}$. Methane concentration was calculated with a standard curve from 0.1 to $1000 \mathrm{mg} \mathrm{kg}^{-1}$ (v/v) (Chang and Yang, 1997; Yang and Chang, 1997). For carbon dioxide analysis, a thermal conductivity detector was used. The column temperature was set at $150^{\circ} \mathrm{C}$. The injection and the detector temperatures were set at $200{ }^{\circ} \mathrm{C}$. Car- bon dioxide concentration was calculated with a standard curve from 0.1 to $1000 \mathrm{mg} \mathrm{kg}^{-1}$ (v/v) (Chang and Yang, 2003).

\subsection{Analytical methods}

Air and soil temperatures were determined with a thermometer. Wind speed was measured with a weathercock (Weather link 4.0, USA). Light intensity was measured with a Toshiba SPI-5 photometer. Soil $\mathrm{pH}$ was determined directly in the tested soils or on 1:1 (w/v) soil to water suspension using a $\mathrm{pH}$ meter. Moisture content was measured by drying a sample at $105^{\circ} \mathrm{C}$ for $24 \mathrm{~h}$ to constant weight. Total organic carbon of the soil or leachate was estimated using a TOC-5000A total organic carbon analyzer (Code HI 8424C, Shimadzu, Japan) after proper dilution of the soil or leachate (Yang and Chang, 1997). The redox potential $\left(E_{\mathrm{h}}\right)$ of the soil or leachate was measured with a Hanna No. 081-854 potentiometer (Yang and Chang, 1997). Total nitrogen was determined with a modified Kjedahl method (Yang et al., 1991). Experiments were carried out in quadruplicate, and flux data were subjected to analysis of the coefficient of variance and Duncan's multiple range tests $(p=0.05)$ using the Statistical Analysis System (SAS Institute, 1988).

\section{Results}

Landfill is the major method of garbage disposal in Taiwan. Landfill disposal was $88.99 \%$ in 1989 and decreased to $71.42 \%$ in 1999 for the increasing of incineration treatment and material recovery policy. The predominant part of the landfill waste soon after disposal becomes anaerobic, and a consortium of bacteria start degrading the solid organic material. Eventually these materials are converted into carbon dioxide, methane and water. Thus, atmospheric concentrations of greenhouse gas, emission rates of carbon dioxide and methane, and other environmental conditions were measured.

\subsection{Greenhouse gas concentration on the campus of National Taiwan University}

As a standard, atmospheric concentrations of greenhouse gas on the campus of the NTU were measured by FTIR spectroscopy method and GC method on December 12, 1997, May 16, 1998 and August 20, 1999 between 11 a.m. and 1 p.m. (Table 3). Gas-type openpath FTIR spectroscopy method had a good correlation with open field GC chamber method. The conversion factors of the concentration with FTIR spectroscopy method to the concentration with open field GC method ranged from 0.986 to 1.008 , from 0.994 to 1.011 , and 
Table 3

Atmospheric concentration of greenhouse gas at different landfill periods of the Shan-Chu-Ku measured by FTIR spectroscopy and GC

\begin{tabular}{|c|c|c|c|c|c|c|c|c|c|c|c|}
\hline \multirow[t]{2}{*}{ Sampling date } & \multirow{2}{*}{$\begin{array}{l}\text { Disposal } \\
\text { period } \\
\text { (year) }\end{array}$} & \multirow{2}{*}{$\begin{array}{l}\text { Detection } \\
\text { method }\end{array}$} & \multicolumn{3}{|c|}{ Carbon dioxide (ppmv) } & \multicolumn{3}{|c|}{ Methane (ppmv) } & \multicolumn{3}{|c|}{ Nitrous oxide (ppbv) } \\
\hline & & & Average & Minimum & Maximum & Average & Minimum & Maximum & Average & Minimum & Maximum \\
\hline \multirow[t]{3}{*}{ May $14-15,1998$} & \multirow[t]{3}{*}{$1-2$} & FTIR & 347 & 293 & 367 & 7.61 & 3.56 & 14.61 & 480 & 330 & 760 \\
\hline & & GC chamber & 560 & 383 & 907 & 28.77 & 8.12 & 55.64 & - & - & - \\
\hline & & GC open field & 341 & 322 & 419 & 7.50 & 4.03 & 16.99 & - & - & - \\
\hline \multirow[t]{3}{*}{ February 25-27, 1998} & \multirow[t]{3}{*}{$2-3$} & FTIR & 310 & 295 & 345 & 12.07 & 4.93 & 17.27 & 688 & 650 & 841 \\
\hline & & GC chamber & 679 & 395 & 1010 & 35.79 & 13.90 & 139.08 & - & - & - \\
\hline & & GC open field & 302 & 293 & 422 & 11.36 & 5.02 & 22.11 & - & - & - \\
\hline \multirow[t]{3}{*}{ May 15-16, 1998} & \multirow[t]{3}{*}{5} & FTIR & 353 & 325 & 376 & 3.40 & 1.88 & 7.06 & 371 & 320 & 675 \\
\hline & & GC chamber & 375 & 353 & 486 & 12.82 & 3.23 & 53.41 & - & - & - \\
\hline & & GC open field & 348 & 325 & 415 & 3.12 & 2.20 & 10.95 & - & - & - \\
\hline \multirow[t]{3}{*}{ December 12, 1997} & \multirow[t]{3}{*}{ Campus } & FTIR & 363 & 350 & 372 & 1.77 & 1.73 & 1.79 & 321 & 316 & 333 \\
\hline & & GC chamber & 362 & 348 & 374 & 1.76 & 1.72 & 1.78 & 320 & 316 & 330 \\
\hline & & GC open field & 361 & 355 & 372 & 1.75 & 1.72 & 1.77 & 324 & 317 & 334 \\
\hline \multirow[t]{3}{*}{ May 16, 1998} & \multirow[t]{3}{*}{ Campus } & FTIR & 362 & 351 & 370 & 1.76 & 1.74 & 1.79 & 321 & 315 & 333 \\
\hline & & GC chamber & 363 & 349 & 373 & 1.77 & 1.73 & 1.80 & 320 & 317 & 330 \\
\hline & & GC open field & 359 & 351 & 372 & 1.76 & 1.75 & 1.80 & 325 & 317 & 334 \\
\hline \multirow[t]{3}{*}{ August 20, 1999} & \multirow[t]{3}{*}{ Campus } & FTIR & 360 & 349 & 370 & 1.77 & 1.74 & 1.78 & 319 & 315 & 334 \\
\hline & & GC chamber & 356 & 331 & 381 & 1.74 & 1.72 & 1.76 & 328 & 305 & 351 \\
\hline & & GC open field & 358 & 342 & 372 & 1.76 & 1.74 & 1.79 & 323 & 315 & 333 \\
\hline
\end{tabular}

Each value was derived from more than 15 independent measurements on the same day. FTIR spectroscopy and GC open field measurement were at $197 \mathrm{~cm}$ height above ground. 
from 0.991 to 1.003 in carbon dioxide, methane and nitrous oxide, respectively. Air temperatures were between 30 and $38{ }^{\circ} \mathrm{C}$. Light intensities ranged from $2.50 \times 10^{5}$ to $1.45 \times 10^{6} \mathrm{~lx}$. Diurnal variation of air temperature was similar to that of light intensity. The effect of air temperature and light intensity on atmospheric concentrations of greenhouse gas was not significant. Therefore, greenhouse gas measurement with FTIR spectroscopy method can be applied in open field.

\subsection{1-2 year-old landfill}

The diurnal variations of atmospheric concentrations of greenhouse gas, carbon dioxide and methane emission rates and environmental conditions in 1-2 year-old landfill during May 14 and 15, 1998 are presented in
Fig. 1, Tables 3 and 4 . The light intensity was high at noon. Atmospheric concentration of carbon dioxide decreased between 3 p.m. and 6 p.m. on May 14, as it rained. Atmospheric concentrations of methane and nitrous oxide were high at night and low in the daytime due to the burning of exit gas in the daytime. The variation of atmospheric concentrations of carbon dioxide and methane measured by GC method (both chamber and open field) was larger than that by FTIR spectroscopy method because of the point measurement in gas chromatographic method while the line determination and the average of 100 times of open field in FTIR spectroscopic method. GC open field method had lower atmospheric concentrations of greenhouse gas than that of chamber method for the mixing effect of the wind and the diffusion of greenhouse gas from landfill to

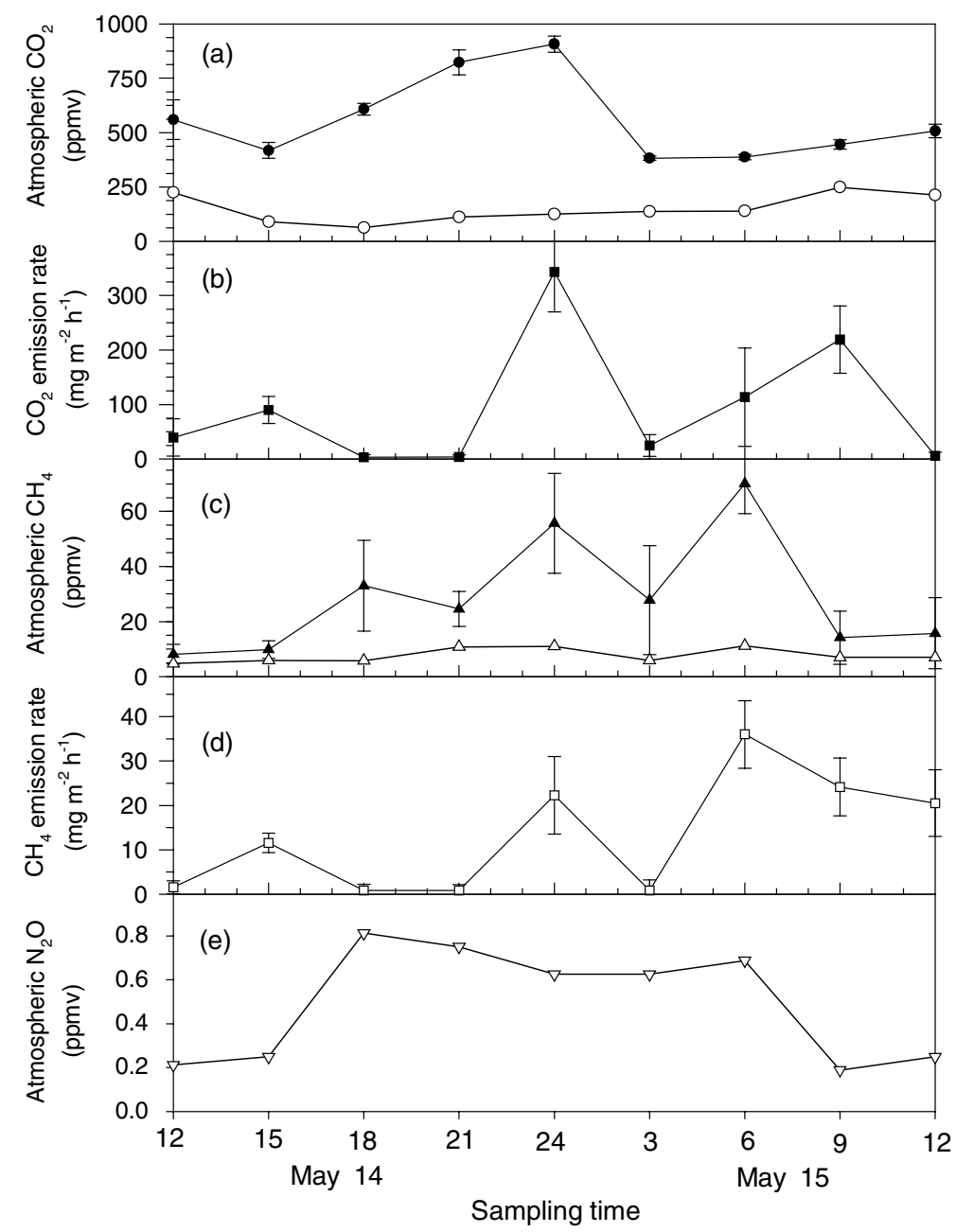

Fig. 1. Diurnal variation of atmospheric greenhouse gas and carbon dioxide and methane emission rates in 1-2 year-old landfill of the Shan-Chu-Ku during May 14-15, 1998. (a) Atmospheric carbon dioxide with FTIR spectroscopy method (O) and with GC method

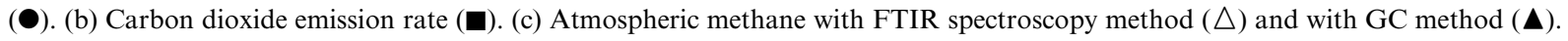
(d) Methane emission rate $(\square)$. (e) Atmospheric nitrous oxide $(\nabla)$ with FTIR spectroscopy method. 


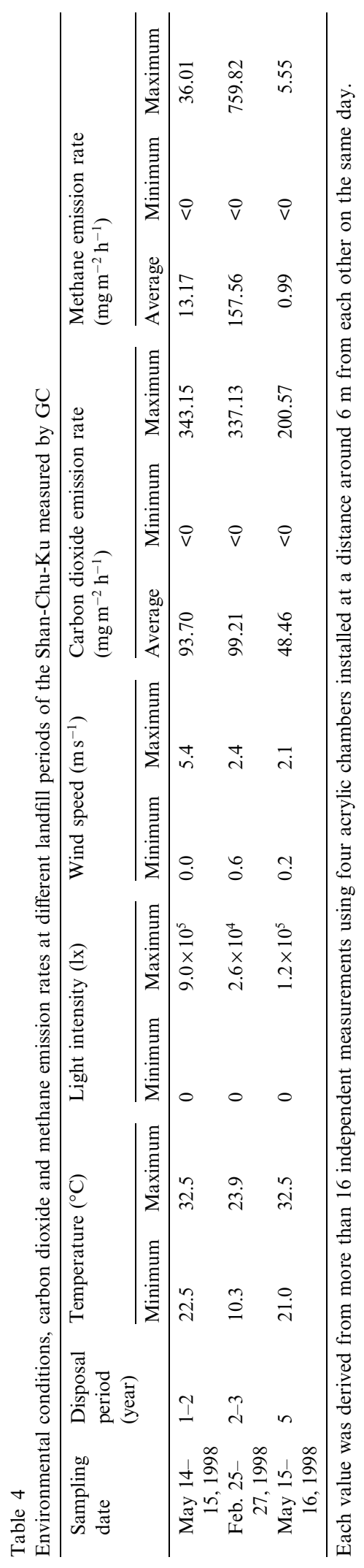

the atmosphere. The fluctuation of atmospheric concentrations of greenhouse gas in landfill was larger than that on the campus of the NTU due to the high emission of greenhouse gas from landfill and the low emission from campus. In addition, carbon dioxide and methane emission rates were high at night and low in the daytime for the burning of exit gas of landfill in the daytime.

\subsection{2-3 year-old landfill}

The diurnal variations of atmospheric concentrations of greenhouse gas, carbon dioxide and methane emission rates and environmental conditions during February 25-27, 1998 are illustrated in Fig. 2, Tables 3 and 4. Atmospheric concentration of carbon dioxide in the daytime was slightly lower than that at night for the photosynthesis of grass and plants in the landfill. Atmospheric concentrations of methane and nitrous oxide were high at noon and low at night due to the low temperature $\left(10.3^{\circ} \mathrm{C}\right)$ in the winter season. The highest air temperature was at noon on February 26 and the lowest was at night on February 25. The highest light intensity observed was at noon on February 26. Both carbon dioxide and methane emission rates had high values at noon for high temperature $\left(23.9^{\circ} \mathrm{C}\right)$. Negative fluxes were sometimes observed in the tested periods when the methane oxidation rate is higher than that of the methane emission rate. Both atmospheric concentrations of greenhouse gas and carbon dioxide and methane emission rates were the highest in 2-3 year-old landfill area among the tested locations for the active degradation of organic wastes and the high total organic carbon content.

Atmospheric concentrations of greenhouse gas and emission rates of carbon dioxide and methane in this landfill were also measured in January, March, July, September and October 1999, February and March 2000 (Table 5). Atmospheric concentration of carbon dioxide was the highest in March 1999 and the lowest in February 1999. Atmospheric concentration of methane was the highest in January 1999 and the lowest in October 1999. Atmospheric concentration of nitrous oxide was the highest in March 2000 and the lowest in March 1999. Atmospheric concentrations of carbon dioxide, methane and nitrous oxide of tested samples in this landfill had $62.5 \%, 100 \%$ and $100 \%$, respectively higher than those on the campus of NTU. Carbon dioxide emission rate had the highest value in October 1999 and the lowest in February 1999, while the methane emission rate was the highest in February 1999 and the lowest in February 2000. The fluctuation patterns were slight differences between atmospheric concentrations of greenhouse gas and emission rates of carbon dioxide and methane for the former with FTIR spectroscopy measurement and the latter with GC determination. 


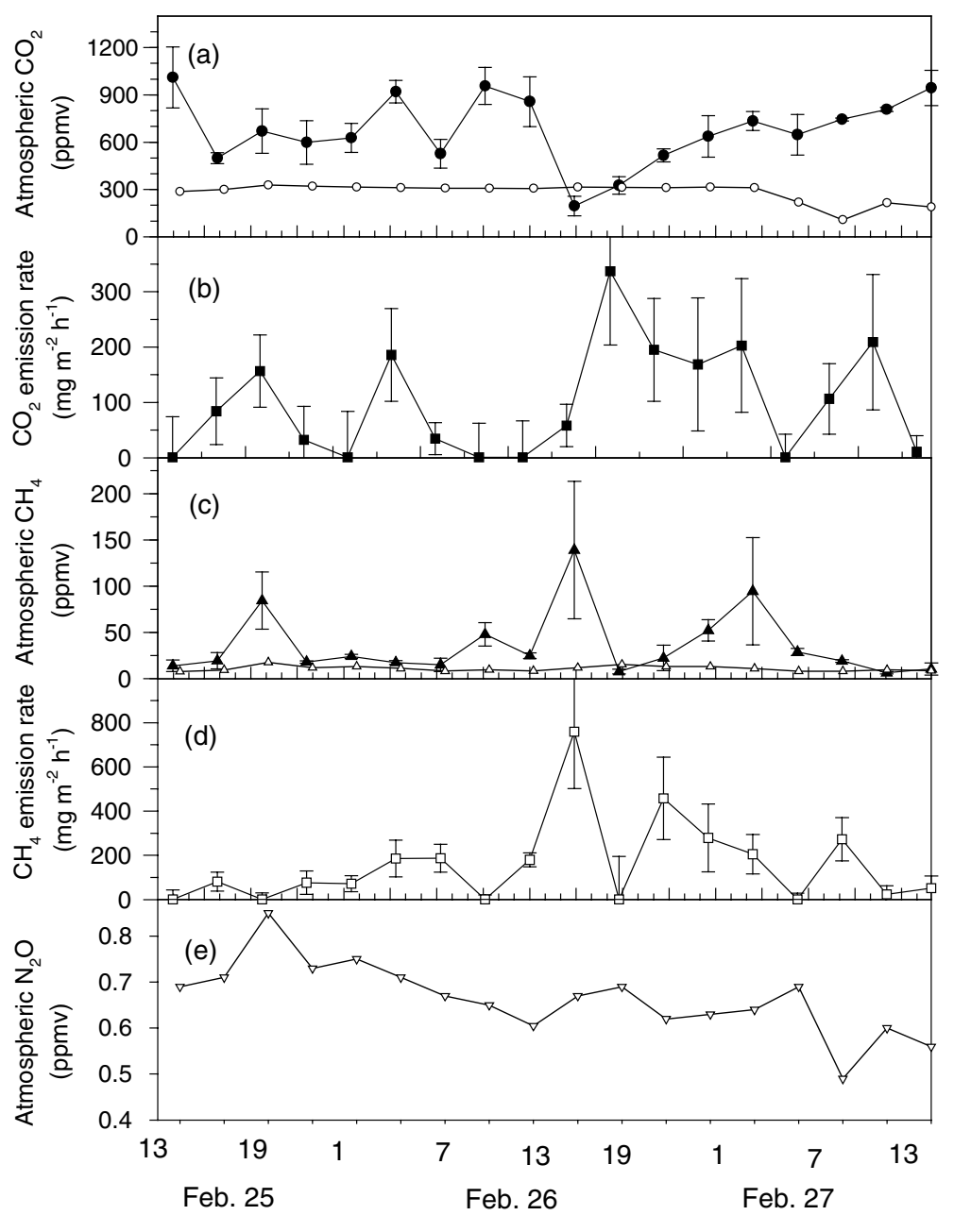

Sampling time

Fig. 2. Diurnal variation of atmospheric greenhouse gas and carbon dioxide and methane emission rates in 2-3 year-old landfill of the Shan-Chu-Ku during February 25-27, 1998. (a) Atmospheric carbon dioxide with FTIR spectroscopy method (O) and with GC method (O). (b) Carbon dioxide emission rate (ם). (c) Atmospheric methane with FTIR spectroscopy method ( $\triangle$ ) and with GC method $(\boldsymbol{\Delta})$. (d) Methane emission rate $(\square)$. (e) Atmospheric nitrous oxide $(\nabla)$ with FTIR spectroscopy method.

\subsection{5 year-old landfill}

Diurnal variations of atmospheric concentrations of greenhouse gas, carbon dioxide and methane emission rates and environmental conditions in the 5 year-old landfill are presented in Fig. 3, Tables 3 and 4. The highest air temperature and light intensity was at noon on May 16 and the lowest was at night on May 15. Atmospheric concentrations of methane and nitrous oxide were also high at night and low in the daytime because of the burning methane in the daytime and high temperature in May. Atmospheric concentration and emission rate of methane were low in this area for longer burial period. Methane emission rate was only $0.63 \%$ and $7.51 \%$ of the $2-3$ and $1-2$ year-old landfill areas, respectively.

\section{Discussion}

Compared to other terrestrial ecosystems, landfills are characterized by high rates of methane production and large methane gradients from the deeper production zone to the soil-atmosphere interface. This is in contrast to methane emission from paddy fields, where the emission rate was high from 11 a.m. to 2 p.m. and was low in the early morning (Yang and Chang, 1998, 1999, 2001b). However, no such correlation has been observed in 
Table 5

Average atmospheric concentrations of greenhouse gas and carbon dioxide and methane emission rates in 2-3 year-old landfill of the Shan-Chu-Ku during January 1999-March 2000

\begin{tabular}{lllcrr}
\hline Sampling date & $\begin{array}{l}\text { Carbon dioxide } \\
(\mathrm{ppmv})\end{array}$ & $\begin{array}{l}\text { Methane } \\
(\mathrm{ppmv})\end{array}$ & $\begin{array}{l}\text { Nitrous oxide } \\
(\mathrm{ppbv})\end{array}$ & $\begin{array}{l}\text { Carbon dioxide emission } \\
\text { rate }\left(\mathrm{mg} \mathrm{m}^{-2} \mathrm{~h}^{-1}\right)\end{array}$ & $\begin{array}{l}\text { Methane emission } \\
\text { rate }\left(\mathrm{mg} \mathrm{m}^{-2} \mathrm{~h}^{-1}\right)\end{array}$ \\
\hline January 1999 & $417.97 \pm 11.00$ & $20.16 \pm 1.37$ & $283.26 \pm 8.00$ & $248.04 \pm 44.50$ & $90.84 \pm 29.00$ \\
February 1999 & $310.03 \pm 9.72$ & $12.07 \pm 3.12$ & $268.78 \pm 6.39$ & $99.21 \pm 42.43$ & $157.60 \pm 25.10$ \\
March 1999 & $530.07 \pm 4.54$ & $10.13 \pm 1.10$ & $258.18 \pm 7.41$ & $309.30 \pm 48.67$ & $78.18 \pm 27.33$ \\
July 1999 & $400.86 \pm 5.82$ & $9.73 \pm 2.87$ & $359.76 \pm 19.17$ & $296.16 \pm 42.67$ & $32.93 \pm 12.00$ \\
September 1999 & $376.73 \pm 7.90$ & $3.52 \pm 0.30$ & $464.14 \pm 10.06$ & $314.60 \pm 42.83$ & $18.61 \pm 5.06$ \\
October 1999 & $397.08 \pm 5.00$ & $2.64 \pm 0.32$ & $1122.60 \pm 21.42$ & $624.60 \pm 63.70$ & $13.47 \pm 6.76$ \\
February 2000 & $354.87 \pm 11.17$ & $8.91 \pm 4.26$ & $1460.19 \pm 26.00$ & $534.10 \pm 26.90$ & $8.91 \pm 2.69$ \\
March 2000 & $323.80 \pm 11.00$ & $4.46 \pm 0.71$ & $1516.17 \pm 17.40$ & $125.32 \pm 17.65$ & $13.91 \pm 1.29$ \\
August 1999/NTU & $360.31 \pm 5.00$ & $1.76 \pm 0.01$ & $319.24 \pm 4.50$ & - & - \\
\hline
\end{tabular}

Each value was derived from more than 15 independent measurements on the same day with FTIR spectroscopy in atmospheric concentrations of greenhouse gas and with GC in emission rates of carbon dioxide and methane using four acrylic chambers installed at a distance around $6 \mathrm{~m}$ from each other.

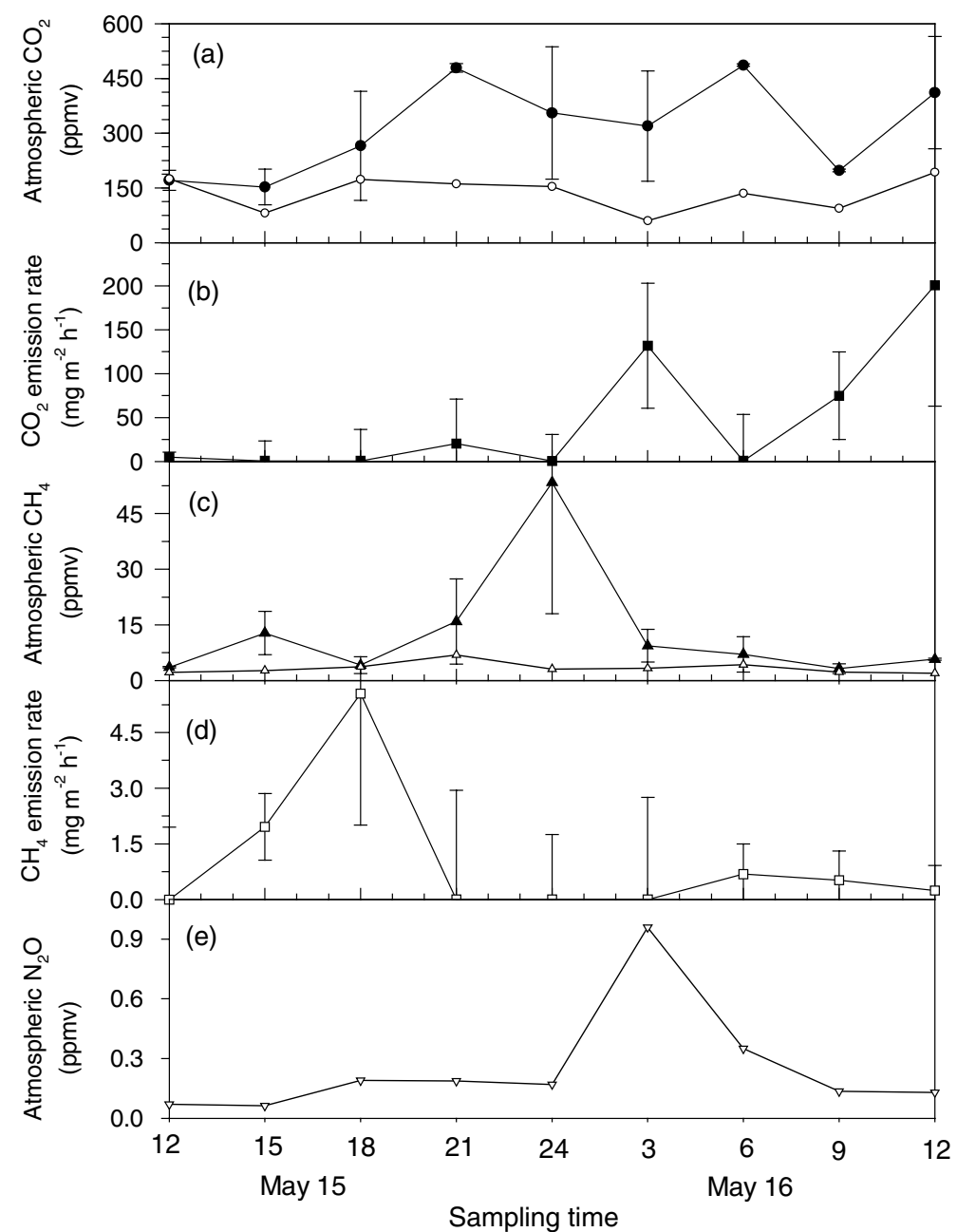

Fig. 3. Diurnal variation of atmospheric greenhouse gas and carbon dioxide and methane emission rates in 5 year-old landfill of the Shan-Chu-Ku during May 15-16, 1998. (a) Atmospheric carbon dioxide with FTIR spectroscopy method (O) and with GC method

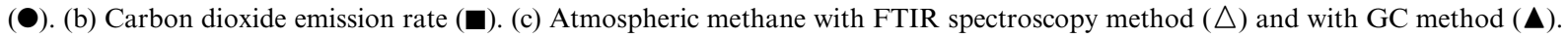
(d) Methane emission rate ( $\square$ ). (e) Atmospheric nitrous oxide $(\nabla)$ with FTIR spectroscopy method. 
landfills during the tested periods. Methane emission rate was high at night and low in the daytime due to the burning of methane in the daytime. Correlation between greenhouse gas emission and air temperature was not obvious in landfill. The fluctuation of soil temperature in the landfill at deeper zone was low, and the effect of air temperature on greenhouse gas emission was not significant when temperature was above $15^{\circ} \mathrm{C}$. However, it showed a positive correlation between methane emission and soil temperature $\left(15-37^{\circ} \mathrm{C}\right)$ in paddy soil (Yang and Chang, 1998). Correlation among air temperature $(T)$, light intensity $(L)$ and atmospheric greenhouse gas concentrations in landfill was $\mathrm{CH}_{4}=18.9287-0.5416 T+$ $0.6229 L$ with a $p$-value $0.0001\left(r^{2}=0.57\right)$ and $\mathrm{CO}_{2}=$ $339.6611+2.2423 T+28.2638 L$ with a $p$-value 2.505 $\left(r^{2}=0.71\right)$. Light might affect the oxygen distribution and penetration in the soil-air interface, and enhance the methane oxidation (Khalil, 1995). King (1990) also indicated that illumination could possibly induce the growth and photosynthesis of algae and the oxidation of methane, but reduce the emission of methane. In contrast, the correlation between methane emission and light intensity in paddy fields was not obvious at low light intensity (between 1000 and 2000 lx) (Yang and Chang, 1998). Therefore, the methane emission pattern in landfills was different from paddy fields. Methane emission from soils depends mainly on soil temperature, moisture content, water table level, organic matter content, redox potential and wind induced ebullition (Bartlett et al., 1992; Yang et al., 1994, 2003; Yang and Chang, 1997, 1998, 2001a,b). However, it is difficult to correlate the exact relationships among greenhouse gas emission rates, temperature, moisture content and composition in landfill due to the heterogeneous nature of the refuse used (Jang and Yang, 2001).

The GC chamber technique gives a point measurement, while gas-type open-path FTIR spectroscopy method gives a line determination. The chamber method can be used to measure greenhouse gas emission rates from small areas of the tested sample, typically less than $1 \mathrm{~m}^{2}$ in each measurement (Yang and Chang, 1999, 2001a). Advantages of this technique include simplicity, an appropriate scale for concurrent measurement of controlling variables (e.g. temperature, $\mathrm{pH}$, soil $E_{\mathrm{h}}$, moisture content, organic matter content), ability to determine the heterogeneity of surface emissions, and ready comparison with other results, since this technique has been widely employed in non-landfill settings for a variety of greenhouse gases (Harriss et al., 1982; Rolston, 1986; Chang and Yang, 1997; Yang and Chang, 1999). However, the variation of GC measurement was high in a long distance heterogeneous field. In contrast, the variation was low using FTIR spectroscopy method due to its ability to compensate for long-distance and more scan number measurements (Chang et al., 2000). Grassland soil on the campus of NTU is more homogeneous than that in landfill and the atmospheric concentrations of greenhouse gas in the grassland of the campus is more uniform than that in landfill. The ratios of atmospheric concentrations of greenhouse gas with GC chamber method to FTIR spectroscopy method in grassland of campus was between 0.989 and $1.003,0.983$ and 1.006, and 0.997 and 1.028 for carbon dioxide, methane and nitrous oxide, respectively. The differences between the ratios of two measuring methods were not significant. However, the ratios of atmospheric concentrations of greenhouse gas in the Shan-Chu-Ku landfill were very significant difference. The ratios of atmospheric concentration of methane were between 2.28 and 4.79, 2.82 and 8.05 , and 1.72 and 7.57 in $1-2,2-3$, and 5 year-old landfills, respectively. The differences of the ratios between campus and landfill might be due to (1) The active decomposition of organic wastes to carbon dioxide, methane and water was found in the landfill. The methane concentration was high in 2-3 year-old landfill. (2) Surface emission measurement with the closed chamber method had higher values than that with open-path field measurement because of the diffusion of methane from the landfill to the atmosphere and the mixing effect of the wind in the open field method. (3) The concentration measurement with FTIR spectroscopy method is the average of 100 scans along the line, while the concentration determination with GC chamber method is only the value of a single sampling point. In addition, the ratios of the highest concentration to the lowest one of atmospheric greenhouse gas with GC measurement were larger than that with FTIR spectroscopy method in all tested sample. FTIR spectroscopy method had a narrow range of the ratios for 100 scans and line detection. Methane emission rate increased at night in most tested locations compared with the same day because the methane was burning in the daytime but not at night.

The properties and the thickness of cover soil were also very important in methane emission from landfill. Although the correlation between methane emission $(X)$ and populations of methane oxidizing microbes $(Y)$ was low. The regression equation was $Y=2.503 X-5 \times 10^{6}$ and $r^{2}=0.078$ (Liao et al., 1998). However, the populations of methane oxidizing microbes increased with the period of burial. Methane oxidation rate $(X)$ had a linear correlation with the populations of methane oxidizing microbes $(Y)$. The regression equation was $Y=8.40 \times$ $10^{4} X-3.0 \times 10^{6}$ and $r^{2}=0.735$ (Liao et al., 1998). Total soil organic carbon of cover soil was $5.97-7.49 \%, 7.78-$ $9.02 \%$ and $5.84-6.67 \%$ in $1-2,2-3$ and 5 year-old landfills, respectively. Methane emission increased with the increasing of total soil organic carbon and total soil nitrogen content, and decreased with the increasing of thickness of cover soil. Kuo et al. (2000) reported that methane emission rate was $0.01,0.054$ and 18.21 $\mathrm{gm}^{-2} \mathrm{~h}^{-1}$ with $1.5-2.9,0.2$ and $0.05 \mathrm{~m}$ thickness of cover soil in Taoyuan landfill site. 
The air temperature of 2-3 year-old landfill site during February 25-27, 1998 was lower than those of 12 year-old and 5 year-old landfill sites during May 14 16, 1998. Carbon dioxide and methane emissions from 2-3 year-old landfill site were not complete comparable with the other two sites for time difference of two-andhalf months earlier than the other sites. Carbon dioxide and methane emissions were still significantly high at the 2-3 year-old landfill site despite the cooler temperature due to the high total organic carbon and total nitrogen contents and high methanogenesis activities. About 2-3 year-old landfill site showed the highest methane emission rate might be due to methanogenesis being fully established. Methane emission rate in the 5 year-old landfill site was very low to negative value. These results suggest that cover soils in this area have high capacity for methane oxidation as Whalen et al. (1990) and Young and Liu (1998) had described. Methane oxidation activity by methanotrophs is higher than that of methane production by methanogens. Atmospheric concentration of carbon dioxide in 5 year-old landfill site was low because of the presence of many trees and small shrubs on this area. Active photosynthesis during daytime consumes carbon dioxide production in the landfill.

Methane emission from the landfill of MSW was affected by methane correction factor, fraction of degradable organic carbon, biogas formation factor, carbon conversion rate (ratio of carbon in biogas to methane) and methane oxidation coefficient. Liao et al. (1998) had estimated the methane emission from the Taichung landfill site by 5 different methods. Methane emission from Taichung landfill site with $1.46 \times 10^{5}$ ton of MSW in 1995 was $1.9,1.7,1.9,3.3$ and $1.4 \times 10^{4}$ ton by heat value, carbon content, chemical composition, physical composition and IPCC methods, respectively. Annual methane emission from Taichung landfill with local measurement was $1.3 \times 10^{4}$ ton that was slight less than IPCC method due to the high methane oxidation activity in cover soil and low dry matter content of MSW. In this study, annual methane emission from the Shan-Chu-Ku landfill was $0.115,0.572$ and $0.009 \mathrm{~kg} \mathrm{~m}^{-2}$ in $1-2,2-3$ and 5 year-old landfill sites, respectively. Methane emission from Shan-Chu-Ku landfill was less than that in Taichung landfill (it was $2.65 \mathrm{~kg} \mathrm{~m}^{-2}$ at the top of landfill, and $12.10 \mathrm{~kg} \mathrm{~m}^{-2}$ in the side edge of landfill) because of the high thickness of cover soil in Shan-Chu-Ku landfill.

Gas-type open-path FTIR spectroscopy method has the advantage in long-distance, precision and rapid measurement. In addition, it can detect different compounds in the meantime (Schäfer et al., 1994) and we have successfully utilized this technique along with GC method to monitor atmospheric concentrations of greenhouse gas in the landfill.

\section{Conclusions}

Both gas-type open-path FTIR spectroscopy method and GC chamber method have been successfully used to measure the atmospheric concentrations of greenhouse gas and carbon dioxide and methane emission rates from landfill. Average methane emission rate was 13.17, 65.27 and $0.99 \mathrm{mg} \mathrm{m}^{-2} \mathrm{~h}^{-1}$ in $1-2,2-3$ and 5 year-old landfills, respectively. Similarly, average carbon dioxide emission rate was $93.70,314.60$ and $48.46 \mathrm{mg} \mathrm{m}^{-2} \mathrm{~h}^{-1}$, respectively. Annual methane and carbon dioxide emission from each hectare of landfill is estimated around 5.717 and 27.61 ton, respectively. About 30 ha is currently in use in the Shan-Chu-Ku landfill, therefore around 171 and 828 ton of methane and carbon dioxide are released to the atmosphere in 1999 , respectively. Taiwan produced 8565820 ton of MSW in 1999, and $71.42 \%$ of the MSW was disposed by landfill. Total carbon dioxide and methane emissions from the landfill were around 10050 and 2075 ton in Taiwan, respectively. Four landfill sites (Shan-Chu-Ku and FuDer-Ken in the north, Chi-Shin-Pu in the south and Taichung in the central Taiwan) have set up a gas recovery system and the maximal electricity generation capacity is estimated $32.7 \mathrm{MW}$. It reduces $5 \%$ methane emission from landfill. In the future 11 potential landfill sites are suitable for methane recovery in Taiwan and the maximal methane reduction expected is $13.4 \%$.

\section{Acknowledgements}

The authors thank Dr. E.H. Chang, Mr. Y.C. Leo and I.C. Chen for their helpful assistances in FTIR spectroscopy measurement, Professor C.T. Liao for statistical analysis, and the National Science Council of the Republic of China for their financial support (NSC87-2621-P002-021, NSC88-2811-Z-002-0001 and NSC89-EPA-Z002-003).

\section{References}

Bartlett, K.B., Crill, P.M., Sass, R.L., Harriss, R.C., Dise, N.B., 1992. Methane emissions from tundra environments in the Yukon-Kuskowim Delta, Alaska. J. Geophys. Res. 97, 16645-16660.

Bogner, J., Meadows, M., Czepiel, P., 1997. Fluxes of methane between landfills and atmosphere; natural and engineered controls. Soil Use Mgmt. 13, 268-277.

Chang, E.H., Yang, S.S., 2003. Some characteristics of microalgae isolated in Taiwan for biofixation of carbon dioxide. Bot. Bull. Acad. Sinca 44, 43-52.

Chang, H.L., Yang, S.S., 1997. Measurement of methane emission from soil. J. Chin. Agric. Chem. Soc. 35, 475-484. 
Chang, T.C., Leo, Y.C., Yang, S.S., 2000. Determination of greenhouse gases by open-path gas-type FTIR spectroscopy. Food Sci. Agric. Chem. 2, 7-14.

Gurijala, K.R., Sulflita, J.M., 1993. Environmental factors influencing methanogenesis from refuse in landfill samples. Environ. Sci. Technol. 27, 1176-1181.

Harriss, R.C., Sebachar, D.I., Day, F.D., 1982. Methane flux in the great dismal swamp. Nature 297, 673-674.

Jang, H.D., Yang, S.S., 2001. Greenhouse gases production of municipal solid wastes in column bioreactors. J. Biomass Energy Soc. China 20, 101-112.

King, G.M., 1990. Dynamics and controls of methane oxidation in a Danish wetland sediment. FEMS Microbiol. Ecol. 74, 309-324.

Khalil, M.A.K., 1995. Greenhouse gases in the Earth's atmosphere. Encycl. Environ. Biol. 2, 251-265.

Kreileman, G.J.J., Bouwman, A.F., 1994. Computing land use emissions of greenhouse gases. Water Air Soil Poll. 76, 231258.

Kuo, K.T., Chang, C.M., Wang, K.S., 2000. Methane flux of landfill and atmospheric methane concentration. In: Yang, S.S. (Ed.), Flux and Mitigation of Greenhouse Gases II. Global Change Research Center, Department of Agricultural Chemistry and Agriculture Exhibition Hall, National Taiwan University, Taipei, Taiwan, pp. 192-204.

Liao, W.P., Horng, C.C., Lee, C.M., 1998. Estimation and monitoring of greenhouse gas emission from Taichung landfill. Final Report of Environmental Protection Administration (EPA87-FA44-03-47). Taipei, Taiwan, p. 320.

Rolston, D.E., 1986. Gas flux. In: Klute, A. (Ed.), Methods of Soil Analysis, second ed. In: American Monograph, vol. 9. American Society Agronomy and Soil Science Society, Wisconsin, pp. 1103-1119.

SAS Institute, 1988. SAS/STAT user's Guide, Release 6.03. SAS Institute, Cary, NC.

Schäfer, K., Haus, R., Heland, J., 1994. Inspection of non- $\mathrm{CO}_{2}$ greenhouse gases from emission sources and in ambient air by Fourier-transform spectrometry: measurements with
FTIS-MAPS. In: Proceedings of the International Symposium on non- $\mathrm{CO}_{2}$ Greenhouse Gases. Kluwer Academic Publishers, Massstricht, pp. 191-196.

Whalen, S.C., Reeburgh, W.S., Sandback, K.A., 1990. Rapid methane oxidation in a landfill cover soil. Appl. Environ. Microbiol. 56, 3405-3411.

Yang, S.S., Chang, E.H., 1997. Effect of fertilizer application on methane production in paddy soils of Taiwan. Biol. Fertil. Soils 25, 245-251.

Yang, S.S., Chang, H.L., 1998. Effect of environmental conditions on methane production and emission from paddy soil. Agric. Ecosyst. Environ. 69, 69-80.

Yang, S.S., Chang, H.L., 1999. Diurnal variation of methane emission from paddy fields at different growth stages of rice cultivation in Taiwan. Agric. Ecosyst. Environ. 76, 75-84.

Yang, S.S., Chang, H.L., 2001a. Effect of green manure amendment and flooding on methane emission from paddy fields. Chem.: Global Change Sci. 3, 41-49.

Yang, S.S., Chang, H.L., 2001b. Methane emission from paddy fields in Taiwan. Biol. Fertil. Soils 33, 157-165.

Yang, S.S., Chang, H.L., Wei, C.B., Lin, H.C., 1991. Reduce waste production in the Kjeldahl methods. J. Biomass Energy Soc. China 10, 147-155.

Yang, S.S., Lin, C.C., Chang, E.H., Chung, R.S., Huang, S.N., 1994. Effect of fertilizer, soil type, growth season on methane production and emission in the paddy soils of Taiwan. J. Biomass Energy Soc. China 13, 68-87.

Yang, S.S., Liu, C.M., Lai, C.M., Liu, Y.L., 2003. Estimation of methane and nitrous oxide emission from paddy fields and uplands during 1990-2000 in Taiwan. Chem.: Global Change Sci. 5.

Young, C.C., Liu, C.W., 1998. Uptake and emission by the addition of greenhouse effect gases in orchard and forest soils in central and southern Taiwan. In: Lu, S.C., Liu, C.M., Yang, S.S. (Eds.), Change of Atmospheric Environments in Taiwan Area III. Global Change Research Center and Department of Agricultural Chemistry, National Taiwan University, Taipei, Taiwan, pp. 54-69. 